Meta

Journal des traducteurs

Translators' Journal

\title{
Templating as a Strategy for Translating Official Documents from Spanish to English
}

\section{Sylvie Lambert-Tierrafría}

Volume 52, numéro 2, juin 2007

URI : https://id.erudit.org/iderudit/016067ar

DOI : https://doi.org/10.7202/016067ar

Aller au sommaire du numéro

Éditeur(s)

Les Presses de l'Université de Montréal

ISSN

0026-0452 (imprimé)

1492-1421 (numérique)

Découvrir la revue

Citer cet article

Lambert-Tierrafría, S. (2007). Templating as a Strategy for Translating Official Documents from Spanish to English. Meta, 52(2), 215-238.

https://doi.org/10.7202/016067ar
Résumé de l'article

Cet article se penche sur la traduction de documents officiels de l'espagnol vers l'anglais. À la suite d'un bref aperçu de l'immigration au Canada, et dans la région d'Ottawa-Gatineau en particulier, ainsi que de sa répercussion sur les besoins en traduction de documents juridiques et officiels, cet article examine les genres de documents requis par Immigration Canada, tels les certificats de naissance, mariage et décès. En dépit de la prolifération de logiciels de traduction, le modèle ou grille de traduction est parfois plus apte à subvenir aux besoins de traducteurs dans de tels cas. Cette approche est non seulement développée mais aussi enseignée dans les cours de traduction espagnole à l'université d'Ottawa au Canada. 


\title{
Templating as a Strategy for Translating Official Documents from Spanish to English
}

\author{
SYLVIE LAMBERT-TIERRAFRÍA \\ University of Ottawa, Ottawa, Canada \\ sylvielambert@sympatico.ca
}

\begin{abstract}
RÉSUMÉ
Cet article se penche sur la traduction de documents officiels de l'espagnol vers l'anglais. À la suite d'un bref aperçu de l'immigration au Canada, et dans la région d'OttawaGatineau en particulier, ainsi que de sa répercussion sur les besoins en traduction de documents juridiques et officiels, cet article examine les genres de documents requis par Immigration Canada, tels les certificats de naissance, mariage et décès. En dépit de la prolifération de logiciels de traduction, le modèle ou grille de traduction est parfois plus apte à subvenir aux besoins de traducteurs dans de tels cas. Cette approche est non seulement développée mais aussi enseignée dans les cours de traduction espagnole à l'université d'Ottawa au Canada.
\end{abstract}

\section{ABSTRACT}

This article examines the case of translation of official documents from Spanish into English in Canada. The article begins by providing some background information about immigration in Canada and in the Ottawa region in particular, and discussing the impact that this is having on translation needs. It then describes the types of official documents that need to be translated (e.g., birth, death, marriage certificates). Next, a type of translation tool known as a Translation Memory is briefly introduced, followed by an explanation of why, contrary to expectations, such a tool is not necessarily suitable for translating official documents. Finally, an alternative strategy that entails the creation and application of templates is presented. This templating approach is being developed and taught in Spanish translation courses at the University of Ottawa in Canada.

\section{MOTS-CLÉS/KEYWORDS}

immigration, Spanish, templating, translation memory, translation of official documents

\section{Introduction}

The volume of text that needs to be translated is on the rise. The reasons for this are varied and include the development of new and more sophisticated products that require accompanying documentation, the introduction of new types of media, such as the World Wide Web, and the increased mobility of people around the world, which has led to a rise in immigration.

As the volume of translation increases, so does the pressure on translators to work more quickly and hence, more efficiently. Some translators turn to computerized tools in the hope that technology may help them increase their productivity. While this may be a reasonable solution in some cases, it is not necessarily a viable strategy in all situations.

This article examines the case of translation of official documents from Spanish into English in Canada. The article begins by providing some general background 
information about immigration in Canada, and by discussing the impact that this is having on translation needs. It then describes the types of official documents that need to be translated (e.g., birth, death, and marriage certificates). Next, a type of translation tool known as a Translation Memory is briefly introduced, followed by an explanation of why, contrary to expectations, such a tool may not necessarily be suitable for translating official documents. Finally, an alternative strategy that entails the creation and application of templates is presented. This templating approach is being developed and taught in Spanish-to-English translation courses at the University of Ottawa in Canada.

\section{Immigration in Canada}

Canada's population is expected to increase by five million by the middle of this century, defying a global trend that will likely see many developed countries lose population. In its forecast for 2050, the U.S.-based Population Reference Bureau projected that the number of inhabitants in Canada will rise to nearly 37 million, up from the current 32 million (PRB 2005: 8). Despite Canada's low fertility rate of 1.5 children per couple, the population will be bolstered by thousands of immigrants expected to arrive here each year.

The increasing number of immigrants to Canada is making growing demands on translation and court interpretation services in the languages of these immigrants (Barabé 2003: 4). In addition, Canadian nationals may require translation services in languages other than English and French. For example, a growing number of Canadians are opting to marry abroad (e.g., Mexico, Cuba, and the Dominican Republic). Upon their return to Canada, the marriage certificates need to be translated into English or French, and certified. Similarly, Canadian nationals requiring medical treatment while traveling abroad need to have medical reports translated for their family physicians, and for insurance coverage, once they return to Canada.

In 1999, the Canadian Translation Industry Sectoral Committee (CTISC) released a report in which it stated that, while the bulk of translation work in Canada takes place between this country's official languages of English and French, additional languages that are becoming increasingly used include Spanish, German, Portuguese, Chinese, Japanese and Korean. Among these, the language in greatest demand is Spanish (1999: 15). Interestingly, the CTISC notes that although large translation firms tend to work primarily between Canada's official languages, "small firms are more open to working with other languages: $30 \%$ of their revenues derive from combinations involving one of the official languages and a foreign language. The Spanishofficial language combinations alone account for almost $10 \%$ of revenues for small firms" (CTISC 1999: 15).

The CTISC (1999: 52) emphasizes that "knowing a third language well is considered increasingly to be a necessity around the world," and encourages Canadian universities to offer more advanced training in languages in addition to English and French.

In addition, the CTISC reports a gap between employers' expectations and the training acquired by university graduates. Employers who were surveyed "are finding that the universities fall short of meeting expectations regarding required skills and preparation for being on the work force. [...] Translation firms claim that university 
training is too theoretical" (1999: 19). An example of this gap is that, in Canada, to the best of my knowledge, no practical courses are offered to train translators to learn how to translate documents for immigrants, although this type of training is included in the curriculum of some European universities (e.g., Zaro and Truman 1998). Furthermore, no translation course in any Canadian university provides any specific training to prepare students for the national translators' certification examination, namely CTTIC (Canadian Translators, Terminologists and Interpreters' Council).

In an effort to reduce this gap, I have incorporated a number of types of "official document" texts into my Spanish-English translation classes at the University of Ottawa. In addition, because these documents differ from culture to culture, I have integrated examples from a range of Spanish-speaking countries, including Mexico, Colombia, Venezuela, Peru, and Cuba.

\section{Legal and official documents}

Unfortunately, official translation is not always well circumscribed. As pointed out by Roberto Mayoral Ascencio (2003: 1), it overlaps with fields such as oral translation, legal translation, court translating and interpreting, and community interpreting. Nevertheless, he proposes the following broad definition for official translations: "translations that meet the requirements to serve as legally valid instruments in a target country" (2003: 1). These may include birth, death, marriage or divorce certificates, academic transcripts, and legal documents. This specialized field of translation is as important as it is fraught with difficulties, for only in few fields are cultural differences so acute and the consequences of errors so palpable. In a globalizing world, and in the increasingly smaller world we live in, official institutions increasingly depend on translations of official documents, and yet relatively little is being done to develop the necessary skills and tools to help translators working in this field.

As pointed out by Zaro and Truman (1998: 77), the language used in legal and official documents in Spanish and English has some common characteristics: it is highly stereotypical, conventionalized and conservative in nature, with a high proportion of set formulae. In addition, it retains morphological, syntactical and lexical features that are no longer used in other types of texts:

KNOW ALL MEN by the Presents that I, Edward J. Morrison, HEREBY APPOINT Eleanor Abercrombie, hereafter called my Attorney, to act for me in every respect as fully and effectually as I could act in person concerning all my present and future affairs.

AND I HEREBY DECLARE that these presents shall be irrevocable for Twelve months from the date hereof and shall at all times be conclusively binding on me and my personal Representatives in favour of third parties.

IN WITNESS whereof I have hereunto set my hand and affixed my Seal this $23^{\text {rd }}$ day of the month of March in the year of our Lord, One thousand, nine hundred and Ninetyeight.

The main aim of this style of language is to make very specific and precise statements, and to avoid wherever possible connotations and ambiguities, to such an extent that it frequently becomes reiterative and repetitive. Nevertheless, there are significant differences in terms of cultural contexts. The countries of Latin America and of continental Europe (including Spain) have legal systems based on Roman Law, 
whereas those of most of the English-speaking countries (including the Englishspeaking provinces of Canada) are based on Common Law. A good example of such cultural differences becomes apparent in the following divorce decree, issued in Mexico.

En nombre de la República de México y como Oficial único del Registro Civil de este lugar, hago saber a los que la presente vieren y Certifico ser cierto que en el libro número uno Tomo 1 del Registro Civil que es [está in Peninsular Spanish] a mi cargo a la foja(s) [hoja in Peninsular Spanish, but foja in Spanish-speaking America] número(s) 107, se encuentra asentada un acta [acta de divorcio] del tenor siguiente:

In the Name of the Republic of Mexico and as the sole official of the Registry of Births, Deaths and Marriages (commonly known as the Registry Office, and the official in charge of it is known as the Registrar) of this locality, I do solemnly declare to all who may read this document and certify that in book number one Volume 1 of the Civil Register in my keeping on page(s) number(s) 107 is recorded the following certificate [divorce certificate is not a standard legal term in English, but divorce decree would be used to denote the document certifying that an individual's marriage has been dissolved], worded as follows:

Given the differences between legal systems, the translator often has to resort to adaptation and is obliged to convey the message by replacing cultural elements in the source language with their nearest equivalents in the target language.

Zaro and Truman (1998: 77) emphasize that legal translation represents something of a compromise. Translators usually strive to achieve acceptability in both the target language and the cultural references that it contains, especially in official translations, which have a clearly defined role to play in legal processes. One fact that makes life easier for the translators is the constant repetition of set formulae and text types, which can facilitate the translation process (assuming, of course, that the translator has acquired the experience and knowledge to deal confidently with the specialized terminology). This constant repetition of formulae and text types might lead translators to wonder whether Translation Memory tools could be helpful for the translation of official documents.

\section{Legal genres in translation}

A useful innovation in the theory and practice of specialized translation is the concept of genre. According to Alcaraz and Hugues (2002), 'genre' or 'text type' refers to "each of the specific classes of texts characteristic of a given scientific community or professional group and distinguished from each other by certain features of vocabulary, form and style, which are wholly function-specific and conventional in nature."

Texts belonging to a given genre display at least the following stylistic and formal features:

(a) A shared communicative function expressed by means of the same performative verb. For example, all injunctions are in the form of orders that must be strictly complied with, whether they involve performing an act or refraining from a specific action; this peremptory nature of the order is thus built into the text in the form of a warning as to the consequences of non-compliance.

(b) A similar macrostructure, i.e., format or organizational outlines. For instance, all judgements are arranged into a minimum of three basic sections: facts as found, relevant law, and decision or ruling. 
(c) A similar discursive mode of developing the macrostructure (narrative, descriptive, imperative, optative) and similar discourse techniques aimed at satisfying the discourse expectations of the recipient or addressee.

(d) A common lexical and syntactic arrangement of the material and a common set of functional units and formal features, e.g. in statutes and other legislative texts, the abundant use of indefinite pronouns, passives and impersonal forms of the verb,"shall' forms of the future to indicate legal obligation, extensive lists of categories or classes of persons and objects to whom or to which the law applies, and so on.

(e) Common socio-pragmatic conventions, e.g. the hierarchical structure of the judiciary as reflected in the abbreviated titles of different judges, and the appropriate style of address ('my Lord,' 'your Lordships,' 'your Honour,' 'your Worship', together with the highly conventional use of certain verbs or verb phrases in given contexts ('submit,' 'put it to you.' 'crave,' 'petition,' 'pray,' 'grant,' 'give leave,' 'restore [an injunction],' 'discharge [an injunction],' 'strike out,' etc.).

(Alcaraz and Hugues, 2002: 101-102)

The identification of genres is useful for translators since it helps them focus on the particular needs and functions being catered to in the original document, and to look further and deeper into the nature of the particular texts they are dealing with, such as issues of lexical equivalence (polysemy, synonymity), syntactic equivalence (nominalization, passivity, modality, word order) or stylistic equivalence (solemnity, formality, figures of speech and other rhetorical devices, severity or asperity of tone in oral utterances, and so on).

\section{The macrostructure of legal genres: university degrees and diplomas}

A good example of a highly conventional genre is the university degree or diploma. Because of the increasing mobility of university students and researchers, and Canada's growing need for professional and skilled immigrants, translators encounter this type of administrative text on a regular basis. Appendix A includes a typical Cuban university diploma and Appendix B, a Peruvian high-school transcript.

A brief look at the standard layout of English and Spanish examples shows a striking similarity of macrostructure, which may be brought under the following heads:

Identification of the issuing authorities:

Spanish: El Jefe de la Oficina de Registros Académicos Certifica:

English: The Chief Registrar of the University of XXXXXXX hereby attests to the fact that:

Academic justification for the award:

Spanish: ... considerando que, conforme a las disposiciones y circunstancias prevenidas por la legislación vigente ...

English: ... on the recommendation of the Senate of the University .....

Purpose of the certificate (expressed by a performative verb):

Spanish: ... expide el presente título de ...

English: ... does hereby confer upon XXXXXXX the degree of ....

\section{Rights and privileges conferred by the award:}

Spanish: ... que faculta al interesado para disfrutar los derechos que a este título otorgan las disposiciones vigentes...

English: ... with all the rights and privileges appertaining thereto .... 


\section{The marking scale:}

Spanish: Se considera nota desaprobada de "0" a "10" y nota aprobada de "11" a "20."

English: Marking scale: Failing marks range from "0" to " 10 "

and passing marks, from " 11 ” to " 20 ."

\section{Place and date of issue:}

Spanish: En XXXX, a 12 de junio de mil novecientos ochenta y ocho.

English: Drawn up at $X$, this twelfth day of June, nineteen hundred and eighty-eight.

\section{Signature:}

Spanish: El Rector.

English: The University Chancellor/Rector/Board of Trustees.

(Adapted from Alcaraz and Hugues 2002: 103-104)

\section{Certificates}

In many situations, a certificate must look like a certificate in order to be accepted as such, and all efforts must be made to have the translation resemble the original. On more than one occasion, I have spent more time on formatting a template than on the actual translation!

\section{Birth certificates}

Two examples of birth certificates are provided, namely one from Cuba (Appendix C) and the other, from Mexico (Appendix D), to highlight the difference in the amount of detailed information provided in the Mexican birth certificate, compared to the Cuban certificate. Mexico's birth certificate includes a certificate number, the time of birth, the parents' occupation and address, the grandparents' nationality and address, and the witnesses' ages and addresses, not to mention a fingerprint. To facilitate matters for Immigration Canada, I provide my clients with two documents: the verbatim translation of the original birth certificate and a selective translation of the birth certificate, (Appendix E), a format used at the Translation Bureau in Ottawa.

\section{Marriage certificates}

Three samples of marriage certificates are included in the Appendices: one from the Dominican Republic (Appendix F), one from Peru (Appendix G), and one from Mexico (Appendix H), once again to showcase the significant differences between the amount of information required, as well as the different formatting demands required in each case.

Since a growing number of young Canadians are opting to marry in exotic locations such as Cuba or the Dominican Republic, a sample of a Dominican marriage certificate is provided in the Appendix. Two other examples include a marriage certificate from Peru and one from the State of Puebla, Mexico. Again, the Mexican certificate is the most painstakingly detailed and includes information on the witnesses, their occupation and addresses, but crucial information that does not appear in the other countries' certificates, namely whether the marriage contract is subject to joint or separate ownership of property during marriage. Appendix I is a selective translation of a marriage certificate, containing the most important data as far as Canadian immigration authorities and lawyers are concerned. 


\section{Divorce certificates}

Although most divorce proceedings can rarely be pared down to a standard "certificate," Mexico provides a divorce certificate that contains the final outcome of the court sentence. In the sample provided here in Appendix J, only the essential information and the court decision are listed. Most divorce certificates normally contain significantly more details on childcare and alimony.

\section{Death certificates}

Appendix $\mathrm{K}$ is a sample of a death certificate from the state of Veracruz, Mexico. Fortunately, I am pleased to report that over a ten-year period, I have managed to need to create only three such templates.

\section{Police-clearance certificates}

Appendix L is a police-clearance certificate from Spain. Such criminal-record checks are commonly required when immigrants apply for landed-immigrant status in Canada. On more than one occasion, the client has inadvertently allowed the sixmonth validity to elapse and had to apply for a new clearance certificate containing the same information but with a new expiry date.

\section{Translation Memory: a problematic approach for translating official documents}

In recent years, a new type of translation technology known as a Translation Memory has been introduced with the aim of helping translators to increase their productivity. There are a number of detailed descriptions in the literature explaining precisely how a Translation Memory works (e.g., L'Homme 1999; Austermühl 2001; Bowker 2002), so only a brief summary will be provided here. Essentially, a Translation Memory consists of a database of previously translated texts. New source texts to be translated are automatically compared against previous source texts stored in the Translation Memory database. If the computer finds a match between a sentence in the new source text and one in a previous source text, it retrieves this previous source text sentence and its corresponding translation and presents them to the translator, who can then decide whether or not to incorporate this previous translation into the new target text.

Since the idea behind a Translation Memory is to allow translators to "recycle" portions of previously translated texts, this type of technology works best when the texts in question are repetitive in nature (Austermühl 2001: 139). As noted above, official documents such as birth certificates or transcripts, are certainly repetitive, which gives the initial impression that they are good candidates for being translated with the help of a Translation Memory. However, a deeper look reveals that the use of a Translation Memory may not be the most viable strategy for translating such texts.

As previously mentioned, it is small operators, such as freelancers or small firms, which tend to take on the bulk of the Spanish translation work in Canada. Unfortunately, however, they may be less well positioned than larger firms to integrate Translation Memory technology into their workflow. There are several reasons for this, including the format of the source texts, human resources factors, and economic factors. 
Firstly, there is an extremely practical reason that will likely impede translators from employing Translation Memory tools to help with the translation of official documents, and that is the fact that having a source text in electronic form is a pre-requisite for using a Translation Memory. Since the bulk of official documents that need to be translated are made available to the translator in hard copy only, it would be cumbersome and time-consuming to first covert them to electronic form. This would need to be done by either keying in the data, or using optical character recognition software, both of which are error prone and would require careful proofreading and editing to correct any errors that were introduced during this step. As a result, any time that might potentially be saved by using a Translation Memory to recycle relevant parts of a text would likely be lost during the labour-intensive step of converting the source text into electronic form.

In addition, there can be other time-draining factors associated with Translation Memories. Firstly, these are sophisticated tools that often have a steep learning curve - so much so that translators may see an initial drop in productivity (Rode 2000:12). While a large firm may be able to absorb this loss, for a smaller operation, this may not be an option. In a similar vein, Translation Memory can be time-consuming to maintain on a long-term basis. There is a considerable amount of hidden work associated with the maintenance of the Translation Memory databases, and while larger firms may employ someone whose primary responsibility is managing technological tools and resources, in a smaller operation, it is often the translator him - or herself who has to take on these tasks (Rode 2000: 13). This could be costly because time that is spent on database maintenance is time that is not spent translating, and translation is what brings in the money.

A final factor that may deter smaller translation firms or freelancers from adopting Translation Memory technology is that such tools can be prohibitively expensive (Rode 2000: 12). Although prices are beginning to come down, and "lite" versions of some tools are now available, these may still be beyond the reach of some independent translators. This is especially true if a translator has multiple clients who use different products. Since data cannot always be transferred easily between products, ${ }^{1}$ a translator may end up having to buy several different expensive software packages to meet the needs of different clients. This would not only be expensive in terms of initial outlay, but it would also multiply the learning curve since each package differs with regard to interface and features. Maintenance time would also be increased as multiple Translation Memory databases would need to be created and maintained.

\section{Templating: a more viable solution?}

The purpose of this article is to suggest that the creation of templates of official documents offers a viable alternative for translators who are not in a position to employ Translation Memories in their work. Templates can be created using a standard word processor, and consist of those parts of the text that are common to all official documents of a given type. For instance, different templates can be created for "Mexican Birth Certificates," "Cuban Marriage Certificates," "Columbian Death Certificates," "Venezuelan University Transcripts," etc.

Once the templates have been developed, the translator can focus primarily on those parts of the text that correspond to the "blanks" that are filled in on the official 
documents. As straightforward as this may sound, translators need to remain vigilant and never become complacent. Every entry must be checked and double-checked given that certificates are amended and updated on a yearly basis. One such case is that of the Colombian driver's license: a driver's license issued in the 1980s and 1990s used to have permanent validity. Canadian officials, understandably suspicious, required an affidavit from the Colombian Embassy, which also had to be translated, since it was issued in Spanish. Recently, newer versions of Colombian driver's licenses now have an expiry date. In another example, some marriage certificates (e.g., Mexico, see Appendix) clearly indicate whether the marriage is subject to separate ownership of property during marriage [separación de bienes] as opposed to joint ownership of property by husband and wife [sociedad conyugal]; other marriage certificates (e.g., Cuba) make no mention of this fact. Some countries list the names and addresses of at least four witnesses to a marriage (e.g., Mexico), whereas other countries do not (e.g., Cuba). Some countries present both the baptismal certificate and the birth certificate, whereas other countries only submit the official birth certificate.

Given the range of documents submitted from Latin American countries, the Translation Bureau of the Government of Canada has devised a user-friendly "selective translation" of birth and marriage certificates, the purpose of which is to extract the most crucial information, as far as lawyers and Immigration Canada officials are concerned, and which I have provided to my students. To date, I recommend that my students submit both the verbatim translation of a birth or a marriage certificate and include the selective translation at their own discretion. Examples of both types of documents are included in the Appendix.

The creation of a template can be a time-consuming process. For example, the template for the marriage certificate from Puebla, Mexico, which is contained in the Appendix, took the students in my class an average of seven hours to create. This raises a question of ethics, which I discuss with the students: should the initial client - for whom the first template is being created - be charged more than the next client whose translation will take only minutes? In other words, would it be unethical to charge the initial client by the hour, and then charge all other clients from Puebla, Mexico, only on a per-document-basis? Similar issues are currently being debated by translators who use Translation Memory tools (Bowker 2002: 121-122; Cohen 2002: 16-17). In the case of Translation Memories, clients sometimes want to pay a lower rate for translations where a match is found in the database; however, translators argue that the rate of pay should be the same since this potential match must still be evaluated and integrated into the text, which requires professional skill. Returning to the templating example, in my opinion, there should be a standard price for the translation of a marriage certificate that is charged to all clients from Puebla, even if changes need to be made to the translator's original template. After all, the fact that the contents of the certificate may have changed is in no way the client's fault, so that the client should not be required to pay additional charges simply because a translator needs to update a given template.

Organizing and storing the templates for efficient retrieval poses another set of challenges. Not only is there a specific format for a given type of official document for each country, but in many cases, there can be variations between documents issued in different states within a given country, as well as differences between documents issued in different years. As mentioned earlier, driver's licenses are regularly updated. 
Old-fashioned hand-written birth certificates from the 1920s and 1930s, which served as excellent teaching material in my classes to see which students were capable of deciphering illegible hand-writing in their second language, were gradually replaced by type-written documents in the 50s and 60s, and eventually made way for computerized forms often including much more information. Baptism certificates are increasingly rare and replaced by birth certificates only.

How to save the templates is up to each individual. Personally, at first, I could not decide whether to save templates according to the type of document, namely birth, marriage, death, divorce, adoption, or by country. The answer became apparent quite early on when for Mexico alone, I began creating sub-directories for each state, such as Coahuila, Nayarit, Guanajuato, Guerrero, Estado de Mexico, Mexico City, Chihuahua, to name but a few, and another set of sub-directories within each state, when I discovered that a birth certificate from Guadalajara, Jalisco is not identical to a birth certificate from Monterrey, Nuevo León. Also, as mentioned in the introduction, a growing number of Canadian nationals choose to marry in Cancún, Quintana Roo, and return to Canada only to learn that they now need to have their Mexican marriage certificate translated into English or French and certified.

My translation classes are carefully designed to introduce students to all facets of professional translation. In other words, in addition to having students design their own templates, I normally ask them to enclose an invoice with their very first assignment. Students invariably ask me if the template they create should be identical to the original document, and what to do if they come across an error in the document, such as a mis-spelled name. As far as how much to charge a client is concerned, students readily admit that they have no idea what the going rate is in the national capital area, whether they should charge per word, per document, or based on source text or target text. I encourage my students to call several translation agencies in the area to inquire about company rates, and to compare these findings with what translators who are certified by the Association of Translators and Interpreters of Ontario (ATIO) charge, all of which leads to animated class discussions. Invariably, students in my class have had first-hand experience working as interns in translation agencies and provide us with the latest information. I also inform my students about the growing trend in some translation agencies, such as Lexi-tech in Ottawa, to pay their freelance translators by the hour and not by the word.

As boring as translating official documents may sound to the inexperienced, I make a point of including assignments consisting of translations of quasi-illegible hand-written Spanish reports of the medical condition of Canadian tourists who have become ill or injured while on vacation in Latin America, and on occasion, documents involving refugee claimants - whose names have been scrupulously deleted - and the horrors they have endured in their native countries prior to applying for refugee status to be welcomed into Canada. In their evaluations of my classes, students generally find the course stimulating and appreciate the fact that they get to work on "real-life" translations of documents that were useful to people and to the outcome of their lives.

\section{Concluding remarks}

Given the growing volume of text that needs to be translated, and the ever-increasing number of Allophone immigrants welcomed into Canada, Canadian universities 
might want to consider a pro-active approach to the whole process of translation and interpretation training programs. In addition to the languages of our founding fathers, which deserve all-due respect, Canada should consider adopting a more pioneering and pro-active approach by making plans now to incorporate languages such as Mandarin, Cantonese, Punjabi, Portuguese and Spanish into its cultural and linguistic mosaic. ${ }^{2}$ Termium ${ }^{\circledast}$ on-line, for example, which is the linguistic database created and maintained by the Translation Bureau of the Canadian Federal Government, was originally developed to serve translators working between Canada's two official languages, but it now includes Spanish entries, and there are plans to begin including entries in Portuguese and Chinese.

Once the policies are finally implemented, the next step will be to consider how to actually teach the templating strategy: at the moment, students are simply provided with a description or with the help of a visual aid such as a photocopied example, and then told to put it into practice on their own in a computer laboratory or at home later. A much more effective solution would be for students to receive hands-on practice in class and to develop their templates in "real time" while discussing relevant issues as they are encountered. Such an integrated and realistic approach is supported by an increasing number of researchers. For example, Yuste (2000) describes an experiment in integrating technology into a Spanish-English translation course at Staffordshire University in the United Kingdom; Quirion (2003) describes efforts that are being made to integrate technology throughout the translator-training program at the Université du Québec en Outaouais (Canada); Bowker (2003: 71) explains that the integration of technology into the course does not necessarily take away from time spent on other translation skills. In contrast, if properly integrated, it not only allows the students to develop new skills, but can also lead to an intensification of the basic translation curriculum itself. For instance, students who use technology to produce term records or templates, to find solutions in parallel documentation, or to produce actual translations, are reinforcing their basic translation skills as well as developing sound and realistic working practices that can later be applied in the workplace.

In addition to crucial courses on translation theory and comparative stylistics, students are also entitled to professional courses that will prepare them not only to successfully pass the CTTIC admission examination on the first attempt, but how to deal with clients from day-one, whether it be how to negotiate a price or prepare an invoice. If university programs are not equipped to provide this type of training, translation and interpretation companies will eventually learn to rely on their own in-house training programs.

\section{NOTES}

1. The Localisation Industry Standards Association (LISA) is working towards the development of a new Translation Memory eXchange (TMX) standard that will go some way toward alleviating this problem in the future, but for the time being, it remains a serious issue. (http://www.lisa.org/standards/tmx consulted January 12, 2006).

2. Personal communication with Donald Barabé, Vice President - Operations, Translation Bureau, Public Works and Government Services Canada, 14 November 2005. 


\section{REFERENCES}

Alcaraz, E. and B. Hughes (2002): Translation Practices Explained. Volume 4: Legal Translation Explained, Manchester, St. Jerome Publishing.

AustermüHL, F. (2001): Electronic Tools for Translators, Manchester, St. Jerome Publishing.

Barabé, D. (2003): "Localisation in Canada," Localisation Focus: The International Journal for Localisation 2-2, p. 4-5.

Bowker, L. (2002): Computer-aided Translation Technology: A Practical Introduction, Ottawa, University of Ottawa Press.

Bowker, L. (2003): “Teaching Translation Technology: Towards an Integrated Approach.” Trad. e Comun. 12, São Paulo, p. 65-79.

Canadian Translation Industry Sectoral Committee (CTISC) (1999): Survey of the Canadian Translation Industry: Human Resources and Export Development Strategy, <http://www.uottawa.ca/associations/csict/princi-e.htm> (accessed 15 May 2005).

Cohen, B. (2002): «Mémoires et tarification, un débat à finir», Circuit 76, p. 16-17.

L’Homme, M.-C. (1999): Initiation à la traductique. Brossard, Québec, Linguatech.

Mayoral Asencio, R. (2003): Translating Official Documents, Manchester, St. Jerome Publishing.

Population Research Bureau (PRB) (2005): 2005 World Population Data Sheet, <http://www.prb. org/pdf05/05WorldDataSheet_Eng.pdf $>$ (accessed 12 January 2006).

Quirion, J. (2003): «La formation des langagiers aux outils informatiques: état des lieux et perspectives», in Mareschal, G., Brunette, L., Guéval, Z. et E. Valentine (eds.), La formation à la traduction professionnelle, Ottawa, University of Ottawa Press, p. 153-166.

Rode, T. (2000): “Translation Memory: Friend or Foe?," International Journal for Language and Documentation, p. 12-13, <http:www.crux.be/English/IJLD/ILJD_04_TM.pdf> (accessed 15 May 2005).

Yuste, E. (2000): “Translation Instruction in the Y2K: Electronic Corpora, Internet and Translation Technology," in Teaching Translation in the Information Age Workshop (\#501), $7^{\text {th }}$ Conference of the International Society for the Study of European Ideas, University of Bergen, Norway, 14-18 August 2000, <http://www.uib.no/issei2000>.

Zaro, J. J. y M. Truman (1998): Manual de traducción: Textos españoles e ingleses traducidos y comentados, Madrid, Sociedad General Española de Librería.

\section{APPENDICES}

Appendix A Cuban university diploma

Appendix B Peruvian high school transcript

ApPendix C Cuban birth certificate

ApPEndix D Mexican birth certificate

APPENDIX E Selective translation of birth certificate

Appendix F Dominican Republic marriage certificate

ApPendix G Peruvian marriage certificate

Appendix H Mexican marriage certificate

APPENDIX I Selective marriage certificate

Appendix J Mexican divorce certificate

ApPendix K Mexican death certificate

ApPendix L Spanish police-clearance certificate 
APPENDIX A Cuban university diploma

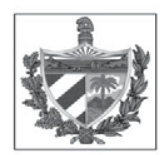

REPUBLIC OF CUBA

MINISTRY OF HIGHER EDUCATION

The Rector of the

Universidad de la Habana

by virtue of the faculties vested in him and on behalf of the Dean of the Faculty, hereby awards the Diploma of

\section{Bachelor of Sciences (Hons) in Physics}

to: $\quad X x x x x x$ Xxxxxx Xxxxxxxxxxxx

in view of the fact that she met all the requirements stipulated for the studies in the specialty and fulfilled all the corresponding exercises for their successful completion, on the tenth day of July, nineteen hundred and ninety-XXXXX.

In witness whereof, the following people sign below in Havana, on the tenth day of the month of July of the year nineteen hundred and ninety-XXXXXX.

$\begin{array}{cc}\text { [illegible signature] } & \text { [illegible signature] } \\ \text { Dean } & \text { Director } \\ \text { Authenticated: } & \end{array}$

[illegible signature]

General Secretary

Registered in volume $\mathbf{X X}$ number $\mathbf{X X X X}$ of the book corresponding to the Secretariat of this Centre of Higher Education. 
APPENDIX B Peruvian high school transcript

\section{MINISTRY OF EDUCATION \\ OFFICIAL TRANSCRIPT \\ SECONDARY EDUCATION FOR MINORS}

REGIONAL/DEPARTAMENTAL BOARD: LIMA SUB-REGIONAL/EDUCATIVE SERVICES UNIT: E.S. S.U. 03

The undersigned Director of the Secondary School / Education Centre / Program ( $\left.{ }^{*}\right)$ :. SAGRADO . CORAZON

"SOPHIANUM"........ Department of LIMA, Province of LIMA, District of San Isidro,

H E R E B Y C E R T I F I E S

That Mr (Mrs): :..Xxxxxx Exxxxxxxx Exxxxxxx. TXxxxxx has successfully completed the: five..............Grade(s)

OF THE SECONDARY-EDUCATION PROGRAM FOR MINORS. The final results obtained are as follows:

\begin{tabular}{|c|c|c|c|c|c|}
\hline COURSES & & & SRADE & & \\
\hline \multirow[t]{2}{*}{ REPUBLIC OF PERU } & First & $\begin{array}{l}\text { Second } \\
\text { "C" }\end{array}$ & $\begin{array}{l}\text { Third } \\
\text { "A" }\end{array}$ & $\begin{array}{l}\text { Fourth } \\
\text { "A" }\end{array}$ & $\begin{array}{l}\text { Fifth } \\
\text { "A" }\end{array}$ \\
\hline & 19-. & 1993 & 1994 & 1995 & 1996 \\
\hline Language and Literature & - & 12 & 11 & 13 & 13 \\
\hline English Language & - & 17 & 16 & 16 & 18 \\
\hline Geography of Peru and of the World & - & 13 & 14 & - & 12 \\
\hline History and Geography & - & - & - & - & - \\
\hline Religious Studies & - & 15 & 16 & 13 & 15 \\
\hline Psychology & $\cdot$ & $\cdot$ & $\cdot$ & 13 & $\cdot$ \\
\hline Civic Education & - & 15 & 13 & 16 & 17 \\
\hline Family and Civics & - & - & - & - & - \\
\hline Economics & - & $\cdot$ & - & $\cdot$ & 12 \\
\hline Philosophy and Logic & - & - & - & - & 15 \\
\hline Mathematics & - & 13 & 11 & 14 & 13 \\
\hline Artistic Education & $=$ & 17 & 17 & 17 & 17 \\
\hline Art and Creativity & - & - & - & - & - \\
\hline Physical Education & - & 15 & 15 & 15 & 15 \\
\hline Family Education & - & 14 & 15 & $\cdot$ & - \\
\hline Natural Sciences & - & 14 & $\cdot$ & $\cdot$ & $\cdot$ \\
\hline Employment Education & $\cdot$ & 17 & 16 & 14 & 17 \\
\hline $\begin{array}{l}\text { Peruvian History within the American and } \\
\text { World Process }\end{array}$ & - & 14 & 13 & 12 & 15 \\
\hline Chemistry & - & - & 13 & - & - \\
\hline Physics & - & - & - & - & 13 \\
\hline Biology & - & - & - & 13 & - \\
\hline
\end{tabular}

As it appears in Minutes and other Archive Documents, the ones I may provide if necessary. EJERCTTO PRESS

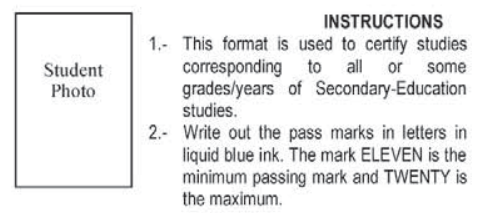

NOVEMBER
19953100,000 UNITS

November 5, 20XX

IN ORDER:

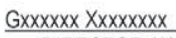

$\operatorname{DIRECTOR}(A)$

Signature, counter-signature and seal

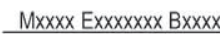
SECRETARY

Signature, counter-signature and seal 
Appendix C Cuban birth certificate

\section{REPUBLIC OF CUBA CIVIL STATUS REGISTRY BIRTH CERTIFICATE}

To be used in:

To be effective in:

\section{REGISTRATION}

Volume | Page XX XXX
yrotirreT lanoitaN

dezilagel ecno seirtnuoc rehtO

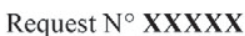

[seal-bearing stamp]
xaT -exempt dexaT

LAW $\mathrm{N}^{0} 73$ DE 4-8-94

\section{DATE OF ENTRY Day | Month | Year \\ Civil Status Registry of Playa} Municipality Playa Province Ciudad de la Habana.

\section{REGISTRY INFORMATION}

First and last names: $\operatorname{XxXXx}$ Xxxxx XxXXXXXXXXXXX.-

Place of birth Playa

Ciudad de la Habana

Municipality Province

$\mathrm{xx}$ October 19xx

Date of Birth

Father's first and last names: Born in:

Mother's first and last names: Born in:

\section{Havana}

Female

Gender

Paternal grandparents $\operatorname{Xxxxxx}$ and $\operatorname{Xxxxx}$

Maternal grandparents $\operatorname{Xxxxyx}$ and $\operatorname{Xxxxx} \mathbf{X x x x x x}$

Registration carried out by virtue of the declaration of the mother

OBSERVATIONS: [none]

THE CIVIL STATUS REGISTRAR OF Playa Ciudad de la Habana

Municipality Province

HEREBY CERTIFIES: That the above information faithfully agrees with the information contained in the above-mentioned registration.

Prepared by: $\operatorname{xxxxx}$

Date of Issue

Compared by: [illegible signature]

\begin{tabular}{ccl}
$\mathbf{x x}$ & $\mathbf{x x x x}$ & $\mathbf{x x x x}$ \\
\hline Day & Month & Year
\end{tabular}

[illegible signature]

CIVIL STATUS REGISTRAR

Seal and signature 
Appendix D Mexican birth certificate

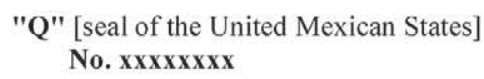

MZO-udear-000

RC-5

CIVIL REGISTRY BIRTH CERTIFICATE

No. $\operatorname{xxxxx}$

Single Population Registration Code 00-000-00-00-00000-0

\begin{tabular}{|c|c|c|c|c|c|c|c|c|}
\hline Entity & Delegation & Court & Certificate & Year & Class & \multicolumn{3}{|c|}{ Year of Registration } \\
\hline $\mathbf{x x}$ & $\mathbf{x x}$ & $\mathbf{x x}$ & $\mathbf{x x x x x}$ & $\mathbf{1 9 x x}$ & BIRTH & $\mathbf{x x}$ & $\mathbf{J U N E}$ & $\mathbf{1 9 x \mathbf { x }}$ \\
\hline
\end{tabular}

\section{REGISTERED INDIVIDUAL}

Name: $\frac{\operatorname{Sxxxxx} \text { Mxxxxx Axxxxxxx }}{\operatorname{din}}$

Date of birth: $\underline{\mathrm{xx} \text { MARCH 19xx }}$

Place of birth: XXXXXXx, BENITO JUAREZ, MEXICO CITY

The following child was presented: A LIVE, MALE CHILD

Declaring parties: BOTH THE MOTHER AND THE FATHER

$$
\text { at } \underline{0: 00 \mathrm{a} . \mathrm{m}} \text {. }
$$

\section{PARENTS}

Father's name: Mxxxxx Mxxxxxx Cxxxxxxx

Nationality: MEXICAN

Mother's name: Axx Gxxxxxx Axxxxxx Sxxxxxxx

Nationality: MEXICAN

Occupation: ENGINEER

Age: $\underline{3 x}$

Occupation: ENGINEER

Address: 10 XXXXxxxxxx, POLANCO, FEDERAL DISTRICT OF MEXICO CITY, [MEXICO

\section{GRANDPARENTS}

Paternal grandfather: Rxxxxxxx Mxxxxxxx Rxxxxxxxx

Paternal grandmother: Axxxxx Cxxxxxxx Sxxxxxx (DECEASED)

Address: Sxxxx Cxxxx, Exxxxxxxxx, STATE OF MEXICO, MEXICO]

Maternal grandfather: Lxxxxx Axxxxxx Axxxxxxx (DECEASED)

Maternal grandmother: Axx Sxxxxxxx Bxxxxxxx

Occupation: HOMEMAKER

Address: 6x Xxxxxx, BENITO JUAREZ, FEDERAL DISTRICT OF MEXICO CITY, [MEXICO]

Nationality: MEXICAN

Nationality: MEXICAN

Nationality: MEXICAN

Nationality: $\overline{\text { MEXICAN }}$

\section{WITNESSES}

Name: Exxxxx Axxxxxx Cxxxxxxxxx Address: $5 x$ Sxx Mxxxxxx, Cxxxxxxx, FEDERAL DISTRICT OF MEXICO CITY, MEXICO]

Name: Exxxxxxx Fxxxxxxx Fxxxxxxxx Nationality: MEXICAN Age: $\underline{6 x}$

Address: 5xx Cxxxxx, Cxxxxxxx, TLALPAN, FEDERAL DISTRICT OF MEXICO CITY

[signature]

[signature]

\section{[fingerprint]}

[signatures and seal]

This act was concluded. For the record, those who signed below included those who were involved and who knew how to sign, otherwise, they left their fingerprint. The act is concluded and hereby authorized. In witness whereof

ON BEHALF OF THE UNITED MEXICAN STATES, AND AS JUDGE OF MEXICO CITY'S CIVIL

REGISTRY, I HEREBY ATTEST TO THE FACT THAT THIS DOCUMENT IS AN EXACT AND

FAITHFUL COPYOF ITS ORIGINAL, AND WHICH I AM HEREBY ISSUING IN Xxxxxx, FEDERAL

DISTRICT OF MEXICO CITY, ON xx Axxxxx 20xx.

$$
\text { [signed] }
$$

CIVIL REGISTRY JUDGE

Jxxx Rxxxxx Lxxxxxxxx 
APPENDix E Selective translation of birth certificate

\section{Sylvie Lambert-Tierrafría}

ATIO-certified Spanish-English translator (\# xxxx) Association of Translators and Interpreters of Ontario Vox: (613) xxx-xxxx-Fax: (613) $x \times x-x \times x x$

E-mail: sylvielambert@sympatico.ca or sylvielambert@rogers.com

SELECTIVE TRANSLATION OF BIRTH CERTIFICATE

\begin{tabular}{|c|c|}
\hline \multicolumn{2}{|r|}{ REGISTERED CHILD } \\
\hline Name & 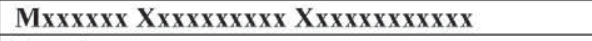 \\
\hline Sex & Female \\
\hline Date of birth & $00 \mathrm{Xxxxx}, 19 \mathrm{xx}$ \\
\hline Place of birth & Havana, CUBA \\
\hline \multicolumn{2}{|r|}{ FATHER } \\
\hline Name & Exxxxxxx Dxxxxxxxxx Rxxxxxxxxxx \\
\hline \multicolumn{2}{|l|}{ Date of birth (or age) } \\
\hline Nationality & CUBAN \\
\hline \multicolumn{2}{|r|}{ MOTHER } \\
\hline Name & Axx Mxxxxxx Xxxxxxxxxx Xxxxxx \\
\hline \multicolumn{2}{|l|}{ Date of birth (or age) } \\
\hline Nationality & CUBAN \\
\hline \multicolumn{2}{|r|}{ DECLARANT } \\
\hline \multicolumn{2}{|l|}{ Name of declarant } \\
\hline \multicolumn{2}{|l|}{ Identification } \\
\hline \multicolumn{2}{|l|}{ Signature of declarant } \\
\hline \multicolumn{2}{|l|}{ Kinship } \\
\hline \multicolumn{2}{|r|}{ REGISTRATION DATA } \\
\hline Date & $06 \mathrm{Xxxxxxx,19xx}$ \\
\hline Place & Havana, Cuba \\
\hline Registration information & Book xxx Page $x x x$ \\
\hline Issuing authority & Civil Status Registrar \\
\hline Date of issue & Xx Xxxxxxx, 19xx \\
\hline Place of issue & Havana, Cuba \\
\hline & OTHER RELEVANT INFORMATION \\
\hline
\end{tabular}


Appendix F Dominican Republic marriage certificate

FORM OC-11

[emblem]

$\mathrm{XXXXXX}$

[bar code]

[crest]

Dominican Republic

CENTRAL ELECTORAL BOARD

VITAL RECORDS OFFICE

EXTRACT OF MARRIAGE CERTIFICATE

(Art. 99, Law No. 669, dated 17-7-1944)

I,

DR. $\mathrm{Xxxxxxx}$ Xxxxxxxx

Official of the Civil Status of SOSÚA, Dominican Republic, HEREBY ATTEST TO THE FACT: That in the archives of which I am in charge, there is a MARRIAGE certificate, registered under number $\underline{\mathbf{x x}}$, Book $\underline{\mathbf{1 - 2 0 x x}}$, Folio $\underline{\mathbf{x x}}$, for the year $\underline{\mathbf{2 0 x x}}$ containing the following information:

Mxxxxx Rxxxxx Bxxxx and Mxxxxx Axxx Pxxxxx Hxxxx: In the city of Sosúa, on the fifth (05) day of the month of JANUARY, in the year two thousand and six (20xx), in the presence of the Civil Registry Official, DR. Xxxxxxxx Xxxxx, the following parties entered into a legal marriage contract: on the one hand, $\mathbf{M x x x x x}$ Xxxxxxxx Xxxxx , Canadian, residing in Canada, professor, bearer of passport number JPxxxxxx, son of Mr. Gxxxxxx Bxxxx and Ms. Mxxxxx Bxxxxx; and on the other hand, Mxxxxxx Axxx Pxxxxxx Hxxxxx , Canadian, residing in Canada, professor, bearer of passport number JPxxxxx, daughter of Mr. Rxxxx Hxxxxx and of Ms.Xxxxx Xxxxx; in the presence of the following witnesses: Nxxxx Pxxxxx Gxxxxx and Exxx Exxxxx Rxxxxxxxx.

NOTES:

[seal and stamp]

S.R.I.

$\operatorname{xxxxxxxxx}$

This extract is issued at the request of the interested party in Sosúa Dominican Republic, on this day, $\underline{\mathbf{0 5} \text { of January }}$ in the year TWO THOUSAND AND $\operatorname{xxxxx}(200 x)$.

[signed]

CIVIL STATUS OFFICIAL 


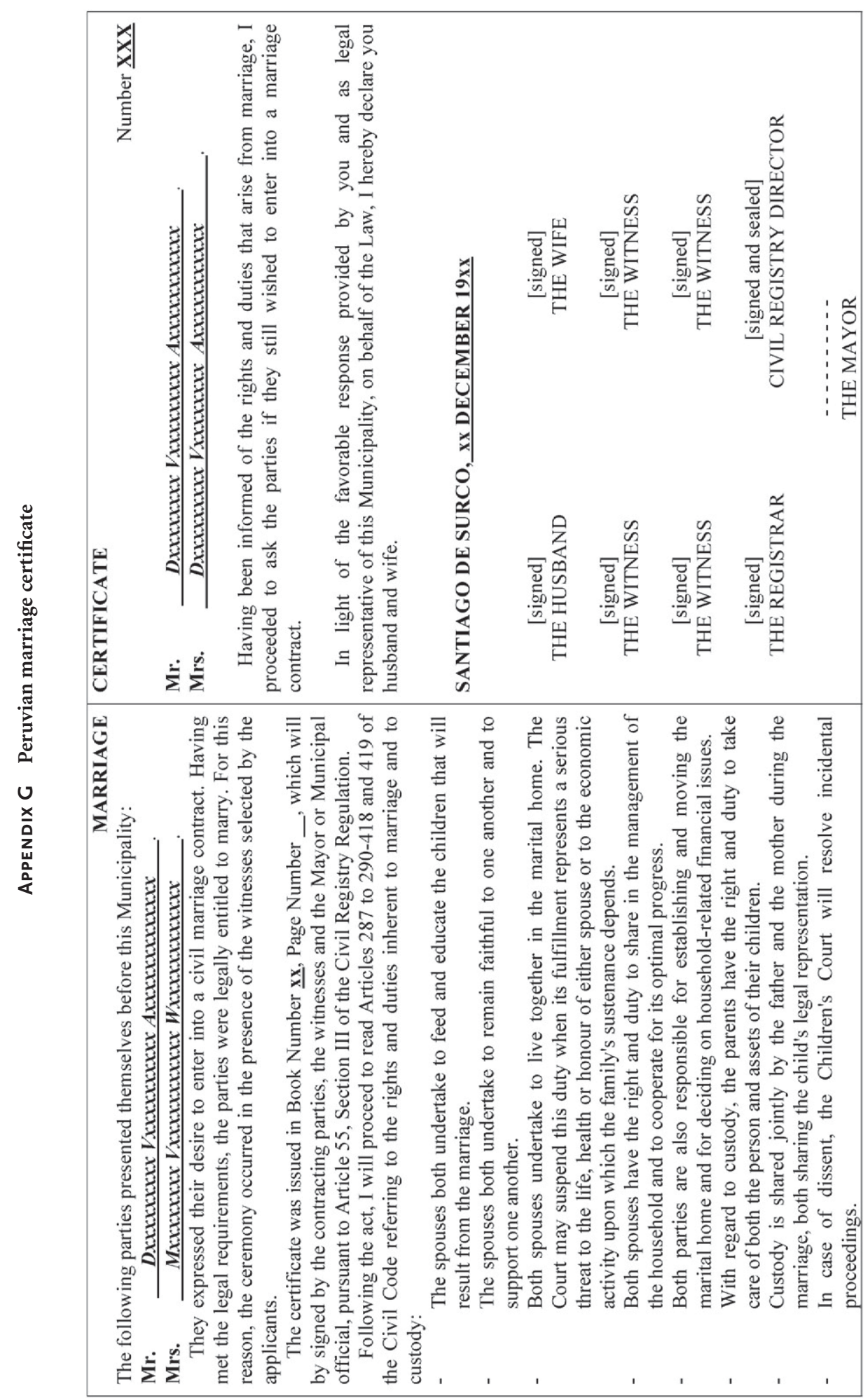


APPENDix H Mexican marriage certificate

The United States of Mexico [seal]

Folio No. $\mathbf{x x x x x}$

MARRIAGE CERTIFICATE

Registration and Personal Identity Code

HIS: 00000000000000

HERS: 00000000000000

THE UNITED STATES OF MEXICO

FREE AND SOVEREIGN STATE OF PUEBLA STATUS REGISTRY OFFICE

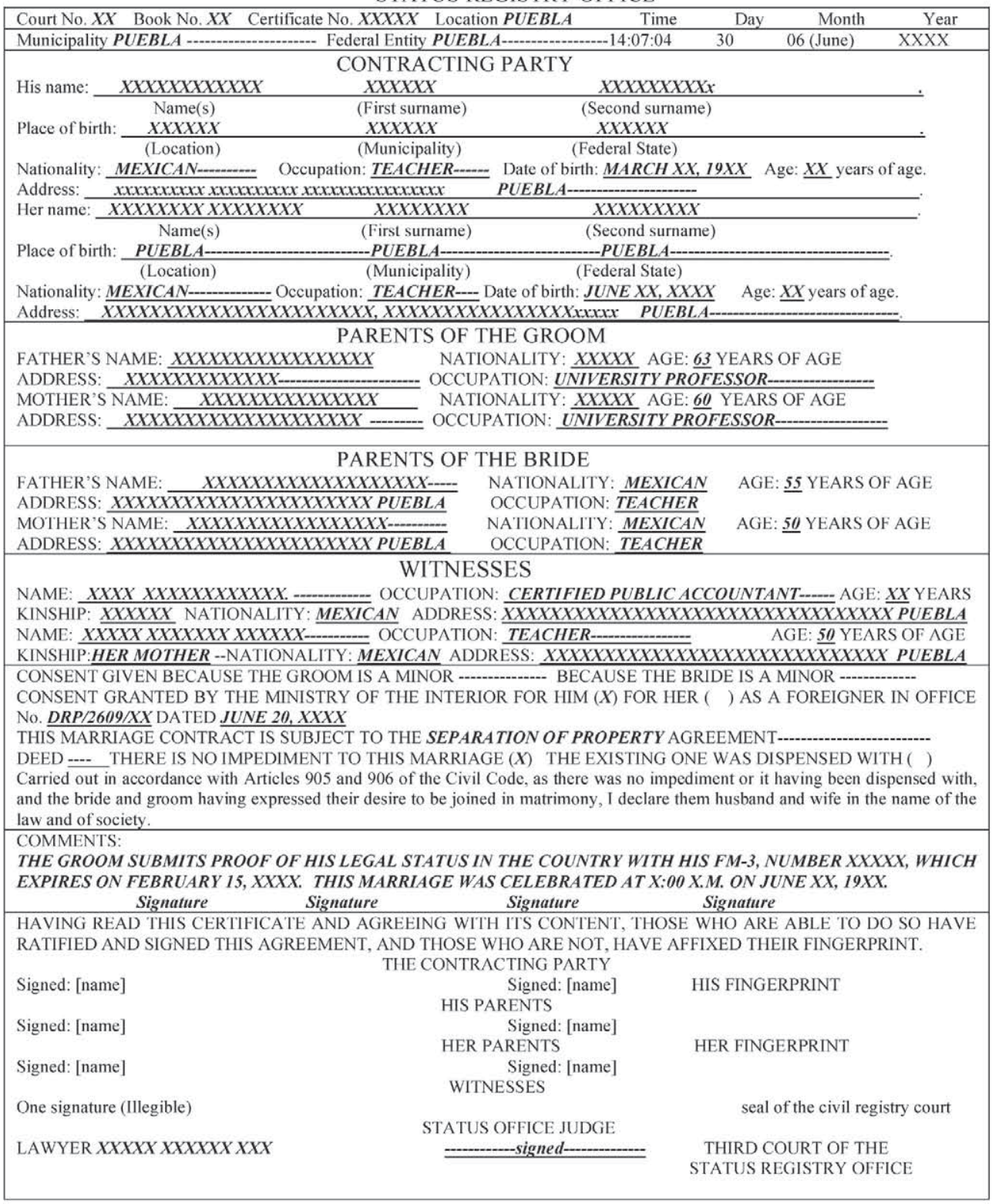


APPENDIX I Selective marriage certificate

SELECTIVE TRANSLATION OF MARRIAGE CERTIFICATE

\begin{tabular}{|c|c|}
\hline \multicolumn{2}{|c|}{ INFORMATION ON THE GROOM } \\
\hline \multicolumn{2}{|l|}{ Name } \\
\hline \multicolumn{2}{|l|}{ Date of birth (or age) } \\
\hline Place of birth & Citizenship: \\
\hline \multicolumn{2}{|l|}{ Birth registration number } \\
\hline Identification card number & Issued at: \\
\hline \multicolumn{2}{|l|}{ Previous marital status } \\
\hline \multicolumn{2}{|l|}{ Father's name } \\
\hline \multicolumn{2}{|l|}{ Mother's name } \\
\hline \multicolumn{2}{|c|}{ INFORMATION ON THE BRIDE } \\
\hline \multicolumn{2}{|l|}{ Name } \\
\hline \multicolumn{2}{|l|}{ Date of birth (or age) } \\
\hline Place of birth & Citizenship: \\
\hline \multicolumn{2}{|l|}{ Birth registration number } \\
\hline Identification card number & Issued at: \\
\hline \multicolumn{2}{|l|}{ Previous marital status } \\
\hline \multicolumn{2}{|l|}{ Father's name } \\
\hline \multicolumn{2}{|l|}{ Mother's name } \\
\hline \multicolumn{2}{|c|}{ REGISTRATION INFORMATION } \\
\hline \multicolumn{2}{|l|}{ Date of marriage } \\
\hline \multicolumn{2}{|l|}{ Place of marriage } \\
\hline \multicolumn{2}{|l|}{ Registration date } \\
\hline \multicolumn{2}{|l|}{ Registration number } \\
\hline \multicolumn{2}{|l|}{ Issuing authority } \\
\hline \multicolumn{2}{|l|}{ Date of issue } \\
\hline \multicolumn{2}{|l|}{ Place of issue } \\
\hline \multicolumn{2}{|c|}{ OTHER RELEVANT INFORMATION } \\
\hline Joint or & ring marriage \\
\hline
\end{tabular}


APPENDIX J Mexican divorce certificate

[seal] The United Mexican States

DIVORCE CERTIFICATE

Registration and Personal Identity Code

THE UNITED STATES OF MEXICO

FREE AND SOVEREIGN STATE OF PUEBLA STATUS REGISTRY OFFICE

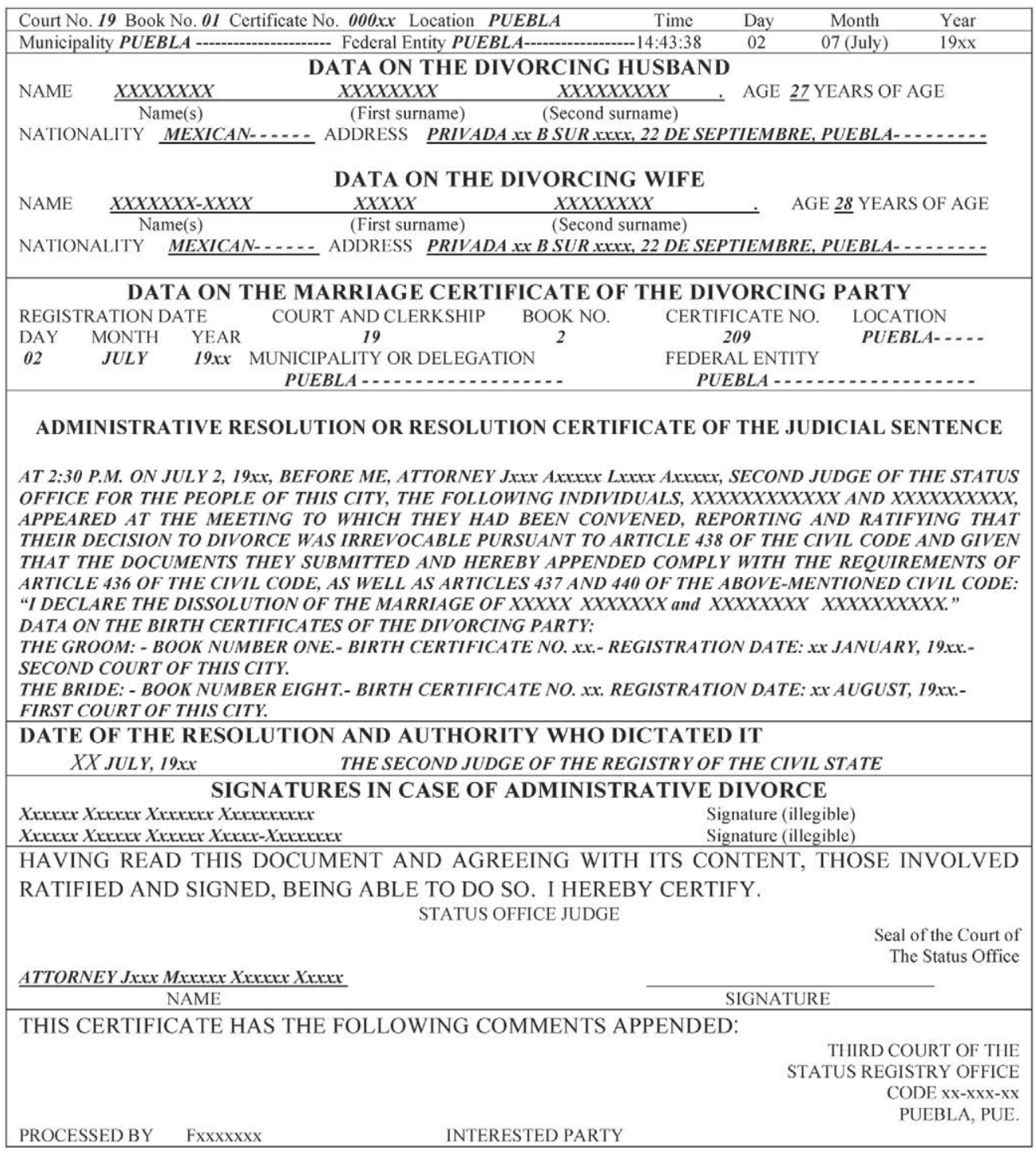




\section{Appendix K Mexican death certificate}

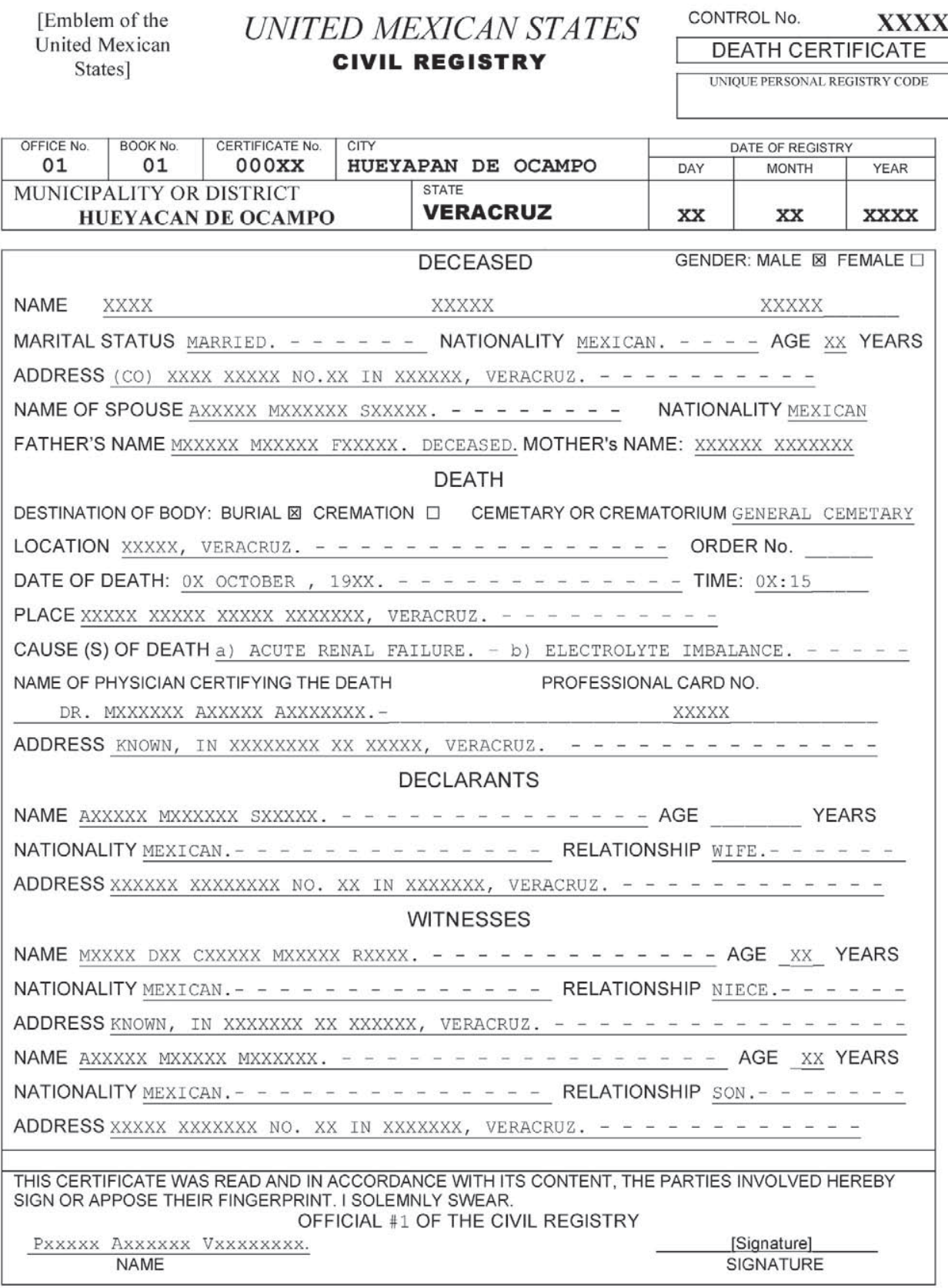


APPENDIX L Spanish police-clearance certificate

SERIES M XXXXXX /OX

Date requested

WRITE IN CAPITAL LETTERS - BEGIN WITH THE FIRST BOX

Day XX Month XX Year XXXX

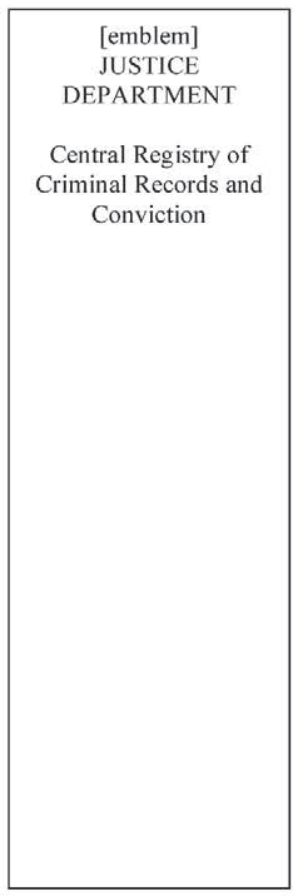

First family surname: $\mathbf{x x x} \mathbf{x x} \mathbf{x} \mathbf{x} \mathbf{x} \mathbf{x} \mathbf{x x x x}$

Second family surname: $\mathbf{X X X X X X X X X X X}$

Name of the interested party: $\mathbf{x x x x} \mathbf{x x x x x x}$

Place of birth (city): $\mathbf{x x x x x x x x x x x x x}$

Province: $\mathbf{x x x x x x}$ Country: $\mathbf{x x x x x x x x x x x}$

Sex: MALE Date of birth: XX OCTOBER XXXX I.D. XXXXXX-X

Father's name

XXXXXXX XXXXXXX

Mother's name

Reason for requesting a criminal record check:

XXXXX XXXX

\section{FOR IMMIGRATION PURPOSES TO CANADA}

THE UNDERSIGNED OFFICIAL HEREBY CERTIFIES:

That after consulting the criminal records notes that are kept in this Central Registry, no record was found that refers to the person whose details are mentioned above.

This certification is to be used solely for the requested purpose, and expires three months after the date of issue (Royal Ordinance of April 1, 1896, Section 3, and January 9, 1914).

Seen and approved

THE OFFICIAL

Head Registrar

\begin{tabular}{|c|}
\hline Cataluña \\
Government \\
seal
\end{tabular}

$\begin{aligned} & \text { [signature] } \\ & \text { MANAGER } \\ & \text { [s.] Xxxxx Xxxxx Xxxxx }\end{aligned}$
[signature]

Signed: Xxxxx Xxxxxx Xxxxxxx

FILL OUT ONLY IF YOU NEED TO RECEIVE THIS CERTIFICATE BY MAIL NO RETURN POSTAGE NECESSARY

15 May XXXX
Name:
Address:
City:
Postal Code: Province:

NOTE: THIS CERTIFICATE IS NULL AND VOID IF IT CONTAINS ANY AMENDMENTS, STRIKETHROUGHS, SCRATCHES, ADDED WORDS OR WORDS BETWEEN LINES 